\title{
STUDI LITERATUR PENGGUNAAN PBL BERBASIS VIDEO UNTUK MENINGKATKAN KEMAMPUAN PEMECAHAN MASALAH
}

\author{
Silvia Wulandari, Nana \\ Pendidikan Fisika Fakultas Keguruan dan Ilmu Pendidikan Universitas Siliwangi, silviaw606@gmail.com
}

\begin{abstract}
Abstrak
Tujuan penelitian ini yaitu untuk mendeskripsikan hasil studi pustaka penggunaan model problem based learning (PBL) berbasis video dalam meningkatkan kemampuan pemecahan masalah siswa pada konsep fluida statis. Penelitian ini dilatar belakangi oleh adanya temuan bahwa keterampilan siswa memecahkan masalah masih dikategorikan rendah. Kondisi ini disebabkan oleh penerapan pembelajaran yang masih tradisional sehingga tidak mampu melatihkan kemampuan pemecahan masalah siswa. Oleh karena itu, diperlukan adanya inovasi baru dengan menerapkan model problem based learning dengan media pembelajaran berbasis video. Metode yang digunakan dalam penelitian ini menggunakan metode atau pendekatan kepustakaan (library research). Hasil penelitian menunjukkan bahwa menerapkan model problem based learning berbasis video sudah behasil dalam meningkatkan kemampuan pemecahan masalah baik secara indvidu maupun kelompok. Kondisi ini didukung oleh pemanfaatan video yang berperan untuk memberikan stimulus awal dalam meenggunakan model problem based learning sehingga menimbulkan motivasi dan ketertarikan siswa dalam pembelajaran fisika.
\end{abstract}

Kata kunci: Problem Based Learning (PBL); Kemampuan Pemecahan Masalah; Video

\section{PENDAHULUAN}

Salah satu ciri dari negara maju adalah negara yang memiliki sumber daya alam dan sumber daya manusia yang berkualitas. Kualitas sumber daya manusia bisa dibentuk dari adanya pendidikan yang memadai. Pembentukkan kualitas sumber daya manusia bisa dilakukan melalui pendidikan secara formal maupun non formal. Pendidikan secara formal dilaksanakan di sekolah. Menurut Yusuf dalam Rafles Sinaga, dkk (2018) mengemukakan bahwa sekolah merupakan lembaga pendidikan formal yang secara sistematis melaksanakan program bimbingan, mengajar, dan latihan dalam rangka membantu siswa agar mampu mengembangkan potensinya, baik yang menyangkut aspek moral, spiritual, intelektual, emosional, maupun sosial. Pendidikan di sekolah tidak bisa terlepas dari adanya pembaharuanpembaharuan dari kurikulum pendidikan itu sendiri. Tujuan dari adanya pembaharuanpembaharuan tersebut yaitu agar terciptanya siswa yang mandiri, unggul, kritis, bertanggungjawab, kreatif, dan inovatif.

Pemerintah negara Indonesia terus
melakukan pembaharuan kurikulum agar
terciptanya peningkatan kualitas pendidikan.
Sampai saat ini, kurikulum yang diterapkan
pemerintah yaitu kurikulum 2013 revisi. Tujuan

dari kurikulum 2013 revisi ini yaitu untuk mempersiapkan manusia agar memiliki kemampuan hidup sebagai pribadi dan warga negara yang beriman, produktif, kreatif, inovatif, dan afektif. Mencapai tujuan dari kurikulum 2013 revisi membutuhkan proses yang tepat. Salah satu cara mencapai tujuan kurikulum 2013 revisi yaitu menerapkan sebuah pendekatan dalam proses pembelajaran. Pendektan yang dianggap tepat dalam proses pembelajaran yaitu menjadikan siswa sebagai pusat dari pendidikan atau sebagai student center sedangkan guru hanya sebagai pengarah dalam proses pembelajaran. Dengan penerapan student center ini siswa menjadi terlatih dan terbiasa menjadi pribadi yang aktif, mandiri, berpikir kritis dan mampu memecahkan masalah dalam proses pembelajaran. Proses pembelajaran yang memusatkan pada siswa (student center) bisa terlaksana dengan baik ketika guru dan siswa sama-sama aktif belajar.

Proses pembelajaran yang menjadikan siswa sebagai pusat (student center) dalam pembelajaran sangat cocok bila diterapkan dalam mempelajari fisika. Fisika merupakan salah satu cabang sains yang menganalisis gejala dan fenomena alam. Pelajaran fisika termasuk salah satu pelajaran yang cukup menarik karena langsung berkaitan dengan kejadian yang nyata dan juga dapat diaplikasikan dalam kehidupan 
sehari-hari. Sehingga dalam mempelajari fisika dibutuhkan suatu proses pembelajaran mandiri yang bisa membekali siswa agar mampu memecahkan masalah sendiri ketika mencari tahu tentang fenomena alam secara sistematis melalui permasalahan yang ada di dalam kehidupan sehari-hari.

Namun sangat di sayangkan, berdasarkan fakta dilapangan diperoleh data bahwa hasil belajar fisika siswa pada umumnya masih dikategorikan rendah. Menurut Silalahi dalam Nana \& Hadi (2019), 60\% dari siswa berpendapat bahwa fisika adalah pelajaran yang sulit dipahami dan kurang menarik dipelajari. Hal ini dikarenakan model pembelajaran yang sangat sering digunakan adalah model pengajaran tradisional yakni ceramah, jarang sekali menggunakan model yang bervariasi. Faktor penyebab rendahnya hasil belajar fisika karena proses pembelajaran di kelas lebih bersifat analitis. Guru menitikberatkan fokus terhadap penurunan-penurunan rumus secara matematis, sehingga siswa berusaha untuk menghafal rumusrumus tanpa mengetahui konsep dasar dan makna dari penggunaan rumus tersebut. Metode yang biasa digunakan guru dalam proses pembelajaran yaitu metode ceramah. Metode ceramah ini biasa digunkan guru untuk menjelaskan, memberi contoh soal, latihan, dan memberikan tugas. Tugas yang diberikan oleh guru pun lebih dominan bersifat matematis sehingga peserta didik yang kurang mampu dalam operasi perhitungan akan mengalami kesulitan. Dengan metode seperti itu membuat sudut pandang belajar fisika itu sangat sulit dan kurang bermakna bagi siswa.

Masalah lain yang ditemukan di kelas yaitu guru kurang melibatkan siswa untuk ikut berpartisipasi secara aktif dalam proses pembelajaran. Sehingga siswa menjadi sangat pasif dan tidak terbiasa untuk memecahkan masalah baik secara autentik maupun akademik. Sedangkan kemampuan pemecahan masalah merupakan salah satu hal yang sangat penting yang harus dimiliki oleh siswa, karena akan berpengaruh terhadap hasil belajar siswa. Siswa yang memiliki kemampuan untuk pemecahan masalah tidak hanya memahami konsep yang telah dipelajarinya, tetapi juga mampu menerapkannya dalam kehidupan yang nyata. Adapun tahap-tahap dalam pemecahan masalah yaitu memahami masalah, merencanakan pemecahan, menyelesaikan masalah, dan memeriksa kembali pemecahan masalah yang telah dilakukan.

Salah satu konsep yang merupakan bagian dari ilmu fisika yaitu fluida statis. Fluida statis merupakan suatu konsep fisika yang erat dengan fenomena alam. Konsep materi fluida statis mencakup hukum tekanan Hidrostatis, Hukum Pascal, Hukum Archimedes dan lain-lain. Dalam kehidupan sehari-hari banyak dijumpai penerapan dari fluida statis, antara lain dalam pembuatan dongkrak mobil dan pembuatan kapal laut. Konsep materi fluida statis mengajarkan siswa untuk berpikir, menemukan masalah dalam kehidupan sehari-hari serta memecahkan masalah berdasarkan teori dan konsep yang sesuai. Konsep yang dimiliki siswa berdasar pengalaman mereka masih terbatas sehingga masih terdapat kesalahan konsep pada materi fluida statis. Padahal menurut Trianto dalam Dahlia, dkk (2017) mengemukakan bahwa pentingnya pemahaman konsep dalam proses pembelajaran sangat mempengaruhi sikap, keputusan, dan cara-cara memecahkan masalah. Berdasarkan hasil penelitian yang pernah dilakukan oleh Chen, dkk (2013) menunjukkan bahwa siswa masih mengalami kesulitan dalam menjelaskan peristiwa terapung, melayang dan tenggelam. Materi fluida statis dipilih dalam penelitian ini karena masih banyak ditemukan kesulitan siswa dalam memahami materi ini khususnya submateri tekanan hidrostatis, hukum Pascal dan hukum Archimedes.

Berdasarkan uraian permasalahan di atas penulis mencoba untuk menggunakan model pembelajaran yang mampu meningkatkan kemampuan siswa dalam pemecahan masalah pada pelajaran fisika terutama pada materi fluida statis. Sesuai dengan pendapat Hertiavi, dkk dalam Rupus, dkk (2019) yang menyatakan bahwa cara dan strategi guru melaksanakan proses pembelajaran sangat berpengaruh terhadap keberhasilan kegiatan pembelajaran. Model pembelajaran yang mampu meningkatkan kemampuan siswa dalam pemecahan masalah yaitu model pembelajaran problem based learning (PBL). Model problem based learning (PBL) 
merupakan suatu model yang membutuhkan penyelidikan autentik yakni penyelidikan yang membutuhkan penyelesaian nyata dari permasalahn yang nyata. Proses pembelajaran problem based learning (PBL) menekankan siswa untuk lebih aktif dalam proses pembelajaran tapi tetap dengan bimbingan guru dalam menemukan konsep terkait. Dalam proses pembelajaran problem based learning (PBL) diharapkan siswa mampu menggunakan pengetahuan yang dimilikinya dan menerapkannya dalam kehidupan sehari-hari. Hal ini didukung oleh pendapat $\mathrm{Ni}$ dalam Acep (2015) bahwa penerapan model problem based learning dimaksudkan untuk meningkatkan partisipasi dan prestasi belajar siswa karena melalui pembelajaran ini siswa belajar bagaimana menggunakan konsep dan proses interaksi untuk menilai apa yang mereka ketahui, mengidentifikasi apa yang ingin diketahui, mengumpulkan informasi dan secara kolaborasi mengevaluasi hipotesisnya berdasarkan data yang telah dikumpulkan.

Hal ini diperkuat dengan hasil penelitian Rahmawati, dkk (2015) yang menyatakan bahwa model pembelajaran problem based learning efektif untuk meningkatkan kemampuan berpikir kritis dan hasil belajar peserta didik. Juniarti (2014) juga menemukan bahwa penerapan model problem based learning (PBL) pada konsep fluida dapat meningkatkan aktivitas belajar siswa, meningkatkan hasil belajar siswa, dan meningkatkan kemampuan pemecahan masalah fisika siswa. Hal ini karena, model pembelajaran problem based learning dapat melatih kemampuan berpikir kritis siswa dalam menyelesaikan masalah, menarik minat siswa dalam pembelajaran dengan adanya interaksi antar siswa untuk mencari solusi, dan menuntut siswa untuk terlibat aktif dalam proses pembelajaran.

Keaktifan dan kemandirian siswa harus tampak dalam setiap proses pembelajaran, maka salah satu media yang bisa guru gunakan untuk menarik perhatian siswa agar berpikir mandiri yaitu dengan menggunakan video. Video merupakan media pembelajaran yang mudah diakses dan dapat menyajikan contoh-contoh fenomena fisika dalam kehidupan sehari-hari, termasuk contoh penerapan fluida statis dalam kehidupan sehari-hari. Oleh karena itu, berdasarkan uraian masalah di atas maka penulis tertarik untuk melakukan penelitian dengan judul: "Studi Literatur Penggunaan PBL Berbasis Video Untuk Meningkatkan Kemampuan Pemecahan Masalah”.

\section{METODOLOGI PENELITIAN}

Metode yang digunakan dalam kajian ini menggunakan metode atau pendekatan kepustakaan (library research). Studi pustaka atau kepustakaan dapat diartikan sebagai serangkaian kegiatan yang berkenaan dengan metode pengumpulan data pustaka, membaca dan mencatat serta mengolah bahan penelitian (Zed, 2003: 3). Dalam penelitian studi pustaka setidaknya ada empat ciri utama yang penulis perlu perhatikan diantaranya: Pertama, bahwa penulis atau peneliti berhadapan langsung dengan teks (nash) atau data angka, bukan dengan pengetahuan langsung dari lapangan. Kedua, data pustaka bersifat "siap pakai" artinya peniliti tidak terjun langsung kelapangan karena peneliti berhadapan langsung dengan sumber data yang ada di perpustakaan. Ketiga, bahwa data pustaka umumnya adalah sumber sekunder, dalam arti bahwa peneliti memperoleh bahan atau data dari tangan kedua dan bukan data orisinil dari data pertama di lapangan. Keempat, bahwa kondisi data pustaka tidak dibatasi oleh rungan dan waktu (Zed, 2003: 4-5). Berdasarkan dengan hal tersebut, maka pengumpulan data dalam penelitian dilakukan dengan menelaah dan/atau mengekplorasi beberapa jurnal nasional dan internasional, buku, serta sumber-sumber data dan atau informasi lainnya yang dianggap relevan dengan penelitian atau kajian untuk dianalisis kemudian disajikan dalam hasil dan pembahasan agar dapat dibuat sebuah kesimpulan.

\section{HASIL DAN PEMBAHASAN}

\section{Model Pembelajaran Problem Based Learning (PBL)}

Menurut Alma dalam Acep (2015) model mengajar merupakan sebuah perencanaan pengajaran yang menggambarkan proses yang ditempuh pada proses belajar mengajar agar dicapai perubahan spesifik pada perilaku siswa seperti yang diharapkan. Komara (2014 : 106) 
menyatakan bahwa model pembelajaran merupakan contoh pola atau struktur pembelajaran siswa yang didesain, diterapkan dan dievaluasi secara sistematis dalam rangka mencapai tujuan. Suatu contoh bentuk pembelajaran yang tergambar dari awal sampai akhir yang disajikan secara khas oleh guru di kelas. Menurut Soekamto dalam Trianto (2009: 22) berpendapat bahwa model pembelajaran merupakan suatu kerangka konseptual yang melukiskan prosedur yang sistematis dalam mengorganisasikan pengalaman belajar untuk mencapai tujuan belajar tertentu, dan berfungsi sebagai pedoman bagi para perancang pembelajaran dan para pengajar dalam merencanakan aktivitas belajar mengajar.

Selain itu, Istarani (2011: 1) juga berpendapat bahwa model pembelajaran adalah seluruh rangkaian penyajian materi ajar yang meliputi segala aspek sebelum, sedang, dan sesudah pembelajaran yang dilakukan guru serta segala fasilitas yang terkait yang digunakan secara langsung atau tidak langsung dalam proses belajar mengajar. Dari penjabaran di atas dapat diambil kesimpulan bahwa model pembelajaran merupakan suatu kerangka acuan yang menggambarkan proses pembelajaran mulai dari sebelum, sedang, dan sesudah pembelajaran untuk mencapai tujuan pembelajaran yang telah ditetapkan oleh guru.

Sebelum menentukan model pembelajaran yang akan digunakan dalam proses kegiatan pembelajaran terdapat beberapa hal yang harus dipertimbangkan oleh guru. Rusman (2012: 133) berpendapat bahwa dasar pertimbangan yang harus dipikirkan oleh guru dalam memilih model pembelajaran diantaranya: 1) Pertimbangan terhadap tujuan yang hendak dicapai; 2) Pertimbangan yang berhubungan dengan bahan atau materi pembelajaran; 3) Pertimbangan dari sudut peserta didik atau siswa; 4) Pertimbangan lainnya yang sifat nonteknis. Pendapat tersebut dapat menjadi pertimbangan bahwa model pembelajaran berbasis masalah atau problem based learning (PBL) merupakan suatu solusi untuk meningkatkan kemampuan pemecahan masalah siswa.
Menurut Arends dalam Dahlia (2017) menyatakan bahwa pembelajaran berbasis masalah atau problem based learning (PBL) merupakan suatu model pembelajaran yang menyuguhkan berbagai situasi bermasalah yang autentik dan bermakna kepada siswa yang berfungsi sebagai loncatan untuk investigasi dan penyelidikan. Pembelajaran berbasis masalah bertujuan untuk memecahkan masalah keseharian yang nyata dan dekat dengan kehidupan siswa. Menurut Arends dalam Elfrida, dkk (2019) mengatakan bahwa model problem based learning (PBL) dirancang terutama untuk membantu siswa mengembangkan keterampilan berpikir, keterampilan menyelesaikan masalah, dan keterampilan intelektualnya, mempelajari peran-peran orang dewasa dengan mengalaminya melalui berbagai situasi riil atau situasi yang disimulasikan, dan menjadi pelajar yang mandiri dan otonom. Menurut Diggs dalam Aweke, dkk (2016) juga menjelaskan bahwa problem based learning (PBL) memungkinkan siswa untuk memahami ilmu pengetahuan yang lebih baik.

Model problem based learning (PBL) adalah model pembelajaran yang mengakomodasi keterlibatan siswa dalam belajar dan pemecahan masalah otentik. Akcay (2009) menyatakan bahwa model problem based learning (PBL) adalah model pembelajaran yang mendorong peserta didik untuk mengenal cara belajar dan bekerjasama dalam kelompok untuk mencari penyelesaian masalah-masalah di dunia nyata. Yuan (2008) menyatakan bahwa PBL adalah model pembelajaran yang berpusat pada siswa untuk belajar, memungkinkan berpartisipasi, dan menghadapi situasi pemecahan dalam kerja kelompok kecil selama proses pembelajaran. Menurut pendapat Rahyubi (2012: 245) dalam pemerolehan informasi dan pengembangan pemahaman tentang topik-topik, siswa belajar bagaimana mengkonstruksi kerangka masalah, mengorganisasikan dan menginvestigasi masalah, mengumpulkan dan menganalisa data, menyusun fakta, mengkonstruksi argument mengenai pemecahan masalah, bekerja secara individual atau berkolaborasi dalam pemecahan masalah.

Dalam model problem based learning (PBL), guru berperan menyodorkan berbagai masalah, memberikan pertanyaan, dan 
memfasilitasi investigasi dan dialog. Pembelajaran berbasis masalah tidak mungkin terjadi kecuali guru menciptakan lingkungan kelas tempat pertukaran ide yang terbuka dan jujur dapar terjadi. Menurut Trianto dalam Acep (2015) model pembelajaran berdasarkan masalah merupakan suatu model pembelajaran yang didasarkan pada banyaknya permasalahan yang membutuhkan penyelidikan autentik, yakni penyelidikan yang membutuhkan penyelesaian nyata dari permasalahan nyata.

Berdasarkan beberapa pendapat di atas mengenai model problem based learning (PBL) dapat disimpulkan bahwa model problem based learning (PBL) merupakan pendekatan pembelajaran yang menyajikan masalah secara kontekstual dengan mengembangkan pemahaman tentang topik-topik. Model problem based learning (PBL) juga melatih siswa untuk belajar bagaimana mengkonstruksi kerangka masalah, mengorganisasikan dan menginvestigasi masalah, mengumpulkan dan menganalisa data, menyusun fakta, mengkonstruksi argument mengenai pemecahan masalah, bekerja secara individual atau berkolaborasi dalam pemecahan masalah.

Menurut Sanjaya dalam Wulandari (2012: 2) model problem based learning (PBL) memiliki beberapa kelebihan antara lain: 1) PBL merupakan teknik yang cukup bagus untuk lebih memahami pelajaran, 2) PBL dapat menantang kemampuan siswa serta memberikan kepuasan untuk menemukan pengetahuan baru bagi siswa, 3) PBL dapat meningkatkan aktivitas pembelajaran, 4) melalui PBL bisa memperlihatkan kepada siswa setiap mata pelajaran (matematika, IPA, dan lain sebagainya), pada dasarnya merupakan cara berfikir, dan sesuatu yang harus dimengerti oleh siswa, bukan hanya sekedar belajar dari guru atau buku-buku saja, 5) PBL dianggap lebih menyenangkan dan disukai siswa, 6) PBL dapat mengembangkan kemampuan berpikir kritis, 7) PBL dapat memberikan kesempatan kepada siswa untuk mengaplikasikan pengetahuan yang mereka milik dalam dunia nyata, 8) PBL dapat mengembangkan minat siswa untuk belajar secara terus-menerus sekalipun belajar pada pendidikan formal telah berakhir.
Selain memiliki kelebihan, model pembelajaran PBL juga memiliki kelemahan. Menurut Sanjaya dalam Wulandari (2012: 2), kelemahan model PBL antara lain: 1) siswa tidak mempunyai minat atau tidak mempunyai kepercayaan bahwa masalah yang dipelajari sulit untuk dipecahkan, maka mereka akan merasa ragu untuk mencoba, 2) keberhasilan model pembelajaran PBL membutuhkan cukup waktu untuk persiapan, 3) tanpa pemahaman mengapa mereka berusaha untuk memecahkan masalah yang sedang dipelajari, maka mereka tidak akan belajar apa yang ingin mereka pelajari.

Menurut Arends (2009) adapun langkahlangkah atau sintaks yang harus dilakukan dalam pembelajaran model problem based learning (PBL) yaitu sebagai berikut.

Tabel 1. Sintaks Pembelajaran Model Problem Based Learning (PBL)

\begin{tabular}{|c|c|}
\hline Fase (Sintaks) & Kegiatan Guru \\
\hline $\begin{array}{l}\text { Tahap 1 } \\
\text { Orientasi siswa } \\
\text { pada masalah }\end{array}$ & $\begin{array}{l}\text { Guru membahas } \\
\text { tujuan pelajaran, } \\
\text { mendeskripsikan dan } \\
\text { memotivasi siswa } \\
\text { untuk terlibat dalam } \\
\text { kegiatan mengatasi } \\
\text { masalah. }\end{array}$ \\
\hline $\begin{array}{l}\text { Tahap 2 } \\
\text { Mengorganisasi } \\
\text { siswa dalam } \\
\text { belajar }\end{array}$ & $\begin{array}{l}\text { Guru membantu } \\
\text { siswa untuk } \\
\text { mendefinisikan dan } \\
\text { mengorganisasikan } \\
\text { tugas-tugas belajar } \\
\text { yang terkait dengan } \\
\text { permasalahannya. }\end{array}$ \\
\hline $\begin{array}{l}\text { Tahap } 3 \\
\text { Menbantu } \\
\text { penyelidikan } \\
\text { individu maupun } \\
\text { kelompok }\end{array}$ & $\begin{array}{l}\text { Guru mendorong } \\
\text { siswa } \\
\text { mengumpulkan } \\
\text { informasi yang } \\
\text { sesuai, melaksanakan } \\
\text { eksperimen, dan } \\
\text { mencari penjelasan } \\
\text { dan solusi. }\end{array}$ \\
\hline $\begin{array}{l}\text { Tahap } 4 \\
\text { Mengembangkan } \\
\text { dan menyajikan } \\
\text { hasil karya }\end{array}$ & $\begin{array}{l}\text { Guru membantu } \\
\text { siswa dalam } \\
\text { merencanakan dan } \\
\text { menyiapkan hasil- } \\
\text { hasil yang tepat, } \\
\text { seperti laporan, }\end{array}$ \\
\hline
\end{tabular}




\begin{tabular}{|l|l|}
\hline & $\begin{array}{l}\text { rekaman video, dan } \\
\text { model-model serta } \\
\text { membantu siswa } \\
\text { untuk } \\
\text { menyampaikan } \\
\text { kepada orang lain. }\end{array}$ \\
\hline $\begin{array}{l}\text { Tahap 5 } \\
\text { Menganalisis dan } \\
\text { mengevaluasi } \\
\text { proses pemecahan } \\
\text { masalah }\end{array}$ & $\begin{array}{l}\text { Guru membantu } \\
\text { siswarak untuk } \\
\text { melakukan refleksi } \\
\text { terhadap } \\
\text { penyelidikan mereka } \\
\text { dan proses-proses } \\
\text { yang mereka } \\
\text { gunakan. }\end{array}$ \\
\hline
\end{tabular}

\section{Kemampuan Pemecahan Masalah}

Menurut A. Aisyah (2017) pemecahan masalah pada dasarnya adalah suatu proses yang ditempuh oleh seseorang untuk menyelesaikan masalah yang dihadapi hingga masalah tersebut tidak lagi menjadi masalah baginya. Untuk memecahkan masalah tersebut, maka seseorang dalam hal ini siswa harus memiliki kemampuan berpikir tingkat tinggi. Sebagaimana menurut Dahar dalam Roni, dkk (2017) mendefinisikan bahwa problem solving abiliy adalah salah satu keterampilan berpikir tingkat tinggi karena siswa harus memiliki kemampuan untuk menggabungkan aturan untuk mencapai solusi. Menurut Hamalik dalam Muhammad Zunanda (2015) mengungkapkan bahwa problem solving adalah suatu proses mental dan intelektual dalam menemukan masalah dan memecahkan berdasarkan data dan informasi yang akurat, sehingga dapat diambil kesimpulan yang tepat dan cermat. Berpikir memecahkan masalah dan menghasilkan sesuatu yang baru adalah kegiatan yang kompleks yang berhubungan erat satu dengan yang lain. Menurut Santrock dalam Ida, dkk (2017) menyatakan bahwa problem solving melibatkan penemuan cara yang tepat untuk mencapai tujuan. Menurut Jonassen dalam Ida, dkk (2017) menyatakan bahwa dalam proses pembelajaran masalah yang diberikan guru bisa berupa permasalahan cerita, permasalahan yang berhubungan dengan membuat keputusan, masalah yang berhubungan dengan penyelesaian dan diagnosis, strategi-performance masalah, menganalisis masalah, dan mendesain penyelesaian masalah.

Menurut Sraswati dalam Kiki, dkk (2019) mengemukakan bahwa kemampuan pemecahan masalah merupakan kemampuan dalam menggunakan proses berfikirnya untuk memecahkan permasalahan melalui suatu tahapan sistematis. Tahapan tersebut mulai dari identifikasi masalah, pengumpulan dan penganalisaan data dan informasi, pemilihan alternatif serta perencanaan tindakan yang bertujuan untuk menemukan solusi. Kemampuan pemecahan masalah fisika adalah hal utama yang harus dimiliki peserta didik sebagai bekal mendapatkan hasil belajar yang maksimal. Pembelajaran fisika bermaksud untuk mengembangkan kemampuan peserta didik dalam menyelesaikan masalah di kehidupan sehari-hari.

Menurut Heller, dkk dalam Sujarwanto (2019) berpendapat bahwa mengajukan langkah penyelesaian masalah dalam pembelajaran fisika melalui lima tahap. Pertama, visualize the problem. Pada langkah ini, dilakukan visualisasi permasalahan dari kata-kata menjadi representasi visual, membuat daftar variabel yang diketahui dan tidak diketahui, identifikasi konsep dasar. Kedua, describe the problem in physics description. Pada langkah ini, representasi visual diubah menjadi deskripsi fisika dengan membuat diagram benda bebas dan memilih sistem koordinat. Ketiga, plan the solution, yaitu merencanakan solusi dengan cara mengubah deskripsi fisika menjadi representasi matematis. Keempat, execute the plan, melaksanakan rencana dengan melakukan operasi matematis. Kelima, check and evaluate, mengevaluasi solusi yang didapatkan dengan mengecek kelengkapan jawaban, tanda, satuan dan nilai.

Sedangkan menurut Young, dkk dalam Sujarwanto (2019) mengajukan penyelesaian masalah fisika dengan menggunakan I SEE. Langkah-langkah pemecahan I-SEE yaitu 1) mengidentifikasi konsep yang relevan (Identify). Pada langkah ini, siswa menggunakan kondisi yang dinyatakan dalam masalah untuk menentukan konsep fisika yang relevan dan mengidentifikasi variabel yang dicari. 2) Set up masalah. Siswa pada langkah ini menentukan 
persamaan yang sesuai untuk memecahkan masalah, membuat sketsa yang mendeskripsikan masalah, dan memilih sistem koordinat. 3) Eksekusi solusi (Execute). Siswa pada langkah ini menggunakan persamaan, mensubstitusi nilai yang diketahui ke persamaan, dan melakukan operasi matematis untuk menemukan solusi. 4) Evaluasi (Evaluation) jawaban. Siswa mengecek satuan dan mengecek kesesuaian dengan konsep.

Adapun penyajian dalam bentuk tabel indikator pemecahan masalah menurut Polya.

Tabel 2. Indikator Pemecahan Masalah

\begin{tabular}{|c|c|}
\hline $\begin{array}{c}\text { Tahap } \\
\text { Pemecahan } \\
\text { Masalah }\end{array}$ & Indikator \\
\hline $\begin{array}{l}\text { Memahami } \\
\text { Masalah } \\
\text { (understand the } \\
\text { problem) }\end{array}$ & $\begin{array}{l}\text { Peserta didik dapat } \\
\text { menyebutkan } \\
\text { informasi-informasi } \\
\text { yang diberikan dan } \\
\text { pertanyaan yang } \\
\text { diajukan }\end{array}$ \\
\hline $\begin{array}{l}\text { Merencanakan } \\
\text { Strategi Pemcahan } \\
\text { Masalah (devising } \\
\text { a plan) }\end{array}$ & $\begin{array}{lr}\text { Peserta } & \text { didik } \\
\text { memiliki } & \text { rencana } \\
\text { pemecahan } & \text { masalah } \\
\text { yang ia gunakan } \\
\text { serta } & \text { alasan } \\
\text { penggunaannya }\end{array}$ \\
\hline $\begin{array}{l}\text { Melakukan } \\
\text { Strategi } \\
\text { Pemecahan } \\
\text { Masalah (carry out } \\
\text { a plan) }\end{array}$ & $\begin{array}{l}\text { Peserta didik dapat } \\
\text { memecahkan } \\
\text { masalah sesuai } \\
\text { langkah-langkah } \\
\text { pemecahan masalah } \\
\text { yang ia gunakan } \\
\text { dengan hasil yang } \\
\text { benar }\end{array}$ \\
\hline $\begin{array}{l}\text { Mengevaluasi } \\
\text { Solusi Pemecahan } \\
\text { Masalah (looking } \\
\text { back at the } \\
\text { completed } \\
\text { solution) }\end{array}$ & $\begin{array}{l}\text { Peserta didik } \\
\text { memeriksa kembali } \\
\text { langkah-langkah } \\
\text { pemecahan masalah } \\
\text { yang digunakan }\end{array}$ \\
\hline
\end{tabular}

Sudah banyak penelitian yang mengukur kemampuan pemecahan masalah (problem solving) terhadap siswa. Pertama penelitian menurut Liezza dalam Emi, dkk mengungkap bahwa penerapan pendekatan problem solving dalam pembelajaran fisika dapat meningkatkan hasil belajar yang lebih baik. Febriana dkk dalam Emi, dkk melaporkan bahwa pendekatan problem solving dapat mengoptimalkan kemampuan berpikir kritis siswa.

\section{Media Pembelajaran Berbasis Video}

Menurut Sadirman dalam Betty, dkk (2015) mengemukakan bahwa penggunaan media pendidikan secara tepat dan bervariasi dapat mengatasi sikap pasif siswa. Selain menggunakan model pembelajaran, media juga mempunyai peranan yang sangat penting. Penggunaan media pembelajaran tentunya dapat membuat siswa menjadi lebih tertarik dan berminat untuk belajar Fisika. Salah satu media yang digunakan untuk menyampaikan suatu pesan mengenai masalah Fisika dalam keseharian adalah media video. Video termasuk ke dalam media audio-visual. Media audio-visual merupakan media yang mengkombinasikan materi auditif yang merangsang pendengaran dan materi visual yang merangsang penglihatan.

Video sebagai media pembelajaran memiliki kelebihan dan kekurangan. Kelebihan video sebagai media pembelajaran antara lain: 1) Merupakan media gerak perpaduan gambar dan suara; 2) Mampu mempengaruhi tingkah laku manusia melebihi media cetak; 3) Dapat digunakan seketika; 4) Dapat digunakan secara berulang; 5) Dapat menyajikan materi yang secara fisik tidak dapat dibawa ke dalam kelas; 6) Dapat menyajikan objek secara detail; 7) Tidak memerlukan ruang gelap; 8) Dapat menyajikan objek yang berbahaya; 9) Dapat diperlambat atau dipercepat; 10) Dapat digunakan untuk klasikal ataupun individual. Kelemahan video sebagai media pembelajaran antara lain: 1) Memerlukan dana yang relatif banyak atau mahal; 2) Memerlukan keahlian khusus; 3) Sukar untuk direvisi; 5) Memerlukan arus listrik.

Penggunaan Model Problem Based Learning (PBL) Berbasis Video Terhadap Kemampuan Pemecahan Masalah Siswa Pada Materi Fluida Statis

Menurut Azizah, dkk dalam Yuberti, dkk (2019) mengemukakan bahwa kemampuan memecahkan masalah adalah keterampilan 
seseorang untuk menemukan solusi melalui proses yang melibatkan memperoleh dan mengorganisir informasi. Adapun tahap-tahap pemecahan masalah manurut Polya yaitu: 1) Memahami masalah; 2) Merencanakan strategi pemcahan masalah; 3) Melakukan strategi pemecahan masalah; 4) Indikator pemecahan masalah; 5) Mengevaluasi solusi pemecahan masalah. Sedangkan indikator pemecahan masalah menurut Polya yaitu: 1) Siswa dapat menyebutkan informasi-informasi yang diberikan dan pertanyaan yang diajukan; 2) Siswa memiliki rencana pemecahan masalah yang ia gunakan serta alasan penggunaannya; 3) Siswa dapat memecahkan masalah sesuai langkah-langkah pemecahan masalah yang ia gunakan dengan hasil yang benar; 4) Siswa memeriksa kembali langkah-langkah pemecahan masalah yang digunakan.

Dalam sebuah proses belajar mengajar, model pembelajaran merupakan suatu hal yang dianggap sangat penting. Model pembelajaran berfungsi sebagai alat yang digunakan guru untuk mencapai tujuan pembelajaran sesuai yang diharapkan. Sebagaimana menurut Isjoni dalam Acep (2015) menyatakan bahwa model pembelajaran merupakan strategi yang digunakan guru untuk meningkatkan motivasi belajar, sikap belajar, mampu berpikir kritis, memiliki keterampilan sosial, dan pencapaian hasil pembelajaran yang lebih optimal dikalangan siswa. Keterampilan siswa dalam memecahkan masalah bisa dibentuk dengan menerapkan model problem based learning (PBL) dalam pembelajaran. Karena model problem based learning (PBL) adalah model pembelajaran yang mengikutsertakan siswa terlibat aktif pada proses pembelajaran. Sehingga, model problem based learning (PBL) sangat memengaruhi kemampuan pemahaman konsep dan kemampuan pemecahan masalah. Hal tersebut sesuai dengan pendapat Hertiavi, dkk dalam Rupus, dkk (2019) yang menyatakan bahwa cara dan strategi guru melaksanakan proses pembelajaran sangat berpengaruh terhadap keberhasilan kegiatan pembelajaran.

Berdasarkan hasil penelelitian Suardani, N. N., dkk (2014) berpendapat bahwa dalam pencapaian kemampuan pemecahan masalah menggunakan model pembelajaran problem based learning lebih baik dibandingkan dengan model pembelajaran langsung. Briana, J., dkk (2015) berpendapat bahwa ada pengaruh yang signifikan dari penerapan model problem based learning (PBL) terhadap kemampuan pemecahan masalah siswa karena pada saat proses belajar dengan menggunakan model problem based learning menuntut siswa belajar secara langsung dengan pemberian pengalaman secara langsung yang berkaitan dengan kehidupan sehari-hari sehingga siswa menemukan dan mampu memecahkan masalah. Supinadi, M.I., dkk (2016) berpendapat bahwa model problem based learning (PBL) secara signifikan meningkatkan kemampuan memecahkan masalah dan hasil belajar kognitif pada siswa. Peningkatan kemampuan memecahkan masalah dan hasil belajar kognitif siswa melalui pembelajaran dengan model problem based learning (PBL) juga diduga karena model problem based learning (PBL) didasarkan pada prinsip bahwa siswa tidak hanya memperoleh pengetahuan tetapi juga bahwa mereka tahu bagaimana menerapkan pengetahuan ini dalam situasi nyata (Sockalingam et al., 2011), termasuk di dalamnya belajar bagaimana belajar (Ibrohim \& Nur, 2002).

Berdasarkan hasil penelitian Suharni dan Rahmatsyah (2020) menunjukkan bahwa ada pengaruh model PBL terhadap kemampuan pemecahan masalah pada materi pokok fluida dinamis. Ini membuktikan bahwa kemampuan pemecahan masalah siswa yang menggunakan model problem based learning (PBL) lebih tinggi daripada model pembelajaran konvensional. Kemampuan pemecahan masalah siswa yang menggunakan model problem based learning (PBL) lebih tinggi daripada model pembelajaran konvensional. Karena kegiatan pembelajaran menggunakan model problem based learning (PBL) diawali dengan dengan kemampuan siswa untuk menyelesaikan masalah nyata yang ditentukan atau disepakati. Proses penyelesaian masalah tersebut berimplikasi pada terbentuknya keterampilan-keterampilan siswa dalam menyelesaikan masalah serta sekaligus membentuk pengetahuan yang baru.

Berdasarkan beberapa hasil penelitian di atas, maka untuk meningkatkan kemampuan 
pemecahan masalah siswa dalam mempelajari materi fluida statis, guru menerapkan model problem based learning (PBL) dalam pelaksanaan pembelajarannya. Sesuai dengan langkah pertama model problem based learning (PBL) ini guru mengorientasi siswa terhadap masalah. Media pembelajaran yang bisa digunakan untuk memberikan stimulus kepada siswa dalam memecahkan masalah yaitu melalui media pembelajaran berupa video. Karena video merupakan sebuah media yang sangat mudah diakses dan mampu memberikan tampilan audiovisual mengenai contoh-contoh penerapan fisika dalam kehdiupan sehari-hari.

\section{KESIMPULAN}

Berdasarkan hasil studi literatur kajian pustaka dari beberapa jurnal nasional dan internasional, buku, serta sumber-sumber data dan atau informasi lainnya yang dianggap relevan dengan penelitian dapat diambil kesimpulan bahwa menggunakan model pembelajaran berbasis masalah atau model pembelajaran problem based learning (PBL) berbasis video ini efektif digunakan karena berhasil untuk mengingkatkan kemampuan pemecahan masalah siswa pada materi fluida statis. Kondisi ini didukung oleh pemanfaatan video yang berperan untuk memberikan stimulus awal dalam meenggunakan model problem based learning (PBL) sehingga menimbulkan motivasi dan ketertarikan siswa dalam kegiatan

\section{DAFTAR PUSTAKA}

Agustiningsih. 2015. "Video" Sebagai Alternatif Media Pembelajaran Dalam Rangka Mendukung Keberhasilan Penerapan Kurikulum 2013 Di Sekolah Dasar. Pancaran, Vol. 4, No. 1, Hal 55-68.

Aisyah, A. 2017. Partisipasi Masyarakat Dalam Mewujudkan Kampung Ramah Anak Melalui Program Inisiasi Kampunge Arek Suroboyo (KAS) Di Kelurahan Jambangan Kecamatan Jambangan Kota Surabaya (Studi Pada RT 7 dan RT 8 RW 3 Kelurahan Jambangan Kecamatan Jambangan Kota Surabaya). Publika, Vol. 5, No. 3. Retrieved from http://jurnalmahasiswa.unesa.ac.id/index.p hp/publika/article/view/18955.

Akcay, B. 2009. Problem-Based Learning in Science Education. Journal of Turkish Science Education. Vol. 6, No. 1.

Al-idrus, S.Q.J., Hikmawati., \& Wahyudi. 2015. Pengaruh Model Pembelajaran Berbasis Masalah Berbantuan Video Kartun Terhadap Hasil Belajar Fisika Siswa Kelas $\mathrm{Xi}$ Sman 1 Sikur Tahun Ajaran 2014/2015. J. Pijar Mipa, Vol. X. No. 1, hal 22-15.

Amir, T. 2008. Inovasi Pendidikan Melalui Problem Based Learning. Jakarta: Prenadamedia Group.

Argaw, A.S., Haile, B.B., Ayalew, B.T., \& Kuma, S.G. 2016. The Effect of Problem Based Learning (PBL) Instruction on Students' Motivation and Problem Solving Skills of Physics. EURASIA Journal of Mathematics Science and Technology Education, Vol. 13, No. 3.

Briana, J., \& M. Turnip, B. 2015. Pengaruh Model Problem Based Learning Terhadap Kemampuan Pemecahan Masalah Siswa SMA. Universitas Negeri Medan.

Dahlia \& Sahyar. 2017. Pengaruh Model Problem Based Learning (PBL) Terhadap Kemampuan Pemecahan Masalah Fisika Siswa Pada Materi Gaya Dan Hukum Newton Di Smp Negeri 1 Pegajahan T.A 2015/2016. Jurnal Ikatan Alumni Fisika Universitas Negeri Medan, Vol. 3, No. 4.

Destianingsih, E., Pasaribu, A., \& Ismet. Pengaruh Model Problem Based Learning Terhadap Kemampuan Pemecahan Masalah Siswa Pada Pembelajaran Fisika Kelas XI Di SMA Negeri 1 Tanjung Lubuk. Jurnal Inovasi Dan Pembelajaran Fisika.

Hamdani, A. R. 2015. Pengaruh Blended Model Problem Based Learning Terhadap Kemampuan Pemecahan Masalah Dan Pemahaman Konsep Siswa Pada Materi 
Daur Air. Jurnal Pendidikan Guru Sekolah Dasar, Vol. 1, No. 1.

Ibrohim \& Nur. 2002. Pengajaran Berbasis Masalah. Surabaya: Universitas Negeri Surabaya.

Istarani, 2011. 58 Model Pembelajaran Inovatif (Reverensi Guru dalam Menentukan Model Pembelajaran), Media Persada, Medan.

Kertinus, R., Darma, Y., \& Wahyudi. 2019. Pengaruh Problem-Based Learning Terhadap Pemahaman Konsep Dan Pemecahan Masalah Dalam Materi Hukum Archimedes. Edukasi: Jurnal Pendidikan, Vol. 17, No, 2.

Komara, Prof. Dr. Endang. 2014. Belajar dan Pembelajar Interaktif, PT. Refika Aditama, Bandung.

Mustafa, S., Sari, V., \& Baharullah. 2019. The Implementation of Mathematical ProblemBased Learning Model as an Effort to Understand the High School Students' Mathematical Thinking Ability. International Education Studies, Vol. 12, No. 2.

Nana \& Pramono, H. 2019. Upaya Peningkatan Kemampuan Kognitif dan Komunikasi Ilmiah Siswa Kelas X MIA 1 SMA Negeri 1 Ciamis Menggunakan Model Pembelajaran Inquiry. Diffraction, Vol 1, No.1.

Polya G, How To Solve It, Princeton, 1973. New Jersey, Princeton University Press.

Purnamasari, I., Yuliati, L., \& Diantoro, M. 2017. Analisis Kemampuan Pemecahan Masalah Fisika pada Materi Fluida Statis. Pros. Seminar Pend. IPA Pascasarjana UM, 2.

Rahyubi, Heri. 2012. Teori-Teori Belajar dan Aplikasi Pembelajaran Motorik. Majalengka: Nusa Media.

Rusman, 2012, Model-Model Pembelajaran Mengembangkan Profesionalisme Guru Edisi Kedua, PT. Rajagrafindo Persada, Jakarta.
Sihaloho, R.R., Sahyar., \& Ginting, E.M. 2017. The Effect of Problem Based Learning (PBL) Model toward Student's Creative Thinking and Problem Solving Ability in Senior High School. IOSR Journal of Research \& Method in Education (IOSRJRME), Vol. 4, No. 1, Hal 11-18.

Sinaga, R., \& Sihombing, E. 2018. Pengaruh Model Problem Based Learning (PBL) Terhadap Kemampuan Pemecahan Masalah Pada Materi Pokok Fluida Statis Di SMA Negeri 1 Silima Punggapungga. Jurnal Inpafi, Vol. 6, No. 4, Hal 1-8.

Simajuntak, E.M., \& Rugaya. 2019. Pengaruh Model Problem Based Learning Terhadap Kemampuan Pemecahan Masalah Siswa Pada Materi Pokok Usaha Dan Energi Di Kelas X Semester II SMA N 9 Medan T. P 2017/ 2018. Jurnal Inpafi, Vol. 7, No. 2, Hal 16-22.

Sockalingam, N. \& Schmidt, H. G. 2011. Characteristics of Problems for ProblemBased Learning: The Students Perspective. The Interdisciplinary Journal of ProblemBased Learning. 5(1): 5-33.

Suardani, N. N., Swasta, I.B.J., \& Widiyanti, N.L.P.M. 2014. Pengaruh Model Pembelajaran Berbasis Masalah Terhadap Kemampuan Pemecahan Masalah dan Keterampilan Proses Sains Siswa. eJournal Program Pascasarjana Universitas Pendidikan Ganesha Program Studi Pendidikan IPA, Vol. 4.

Suharni \& Rahmatsyah. 2020. Pengaruh Model Problem Based Learning (PBL) Terhadap Kemampuan Pemecahan Masalah Fisika Pada Materi Pokok Fluida Dinamis Di Kelas X Semester I SMK Swasta Teladan Medan T.A 2018/2019. Jurnal Inovasi Pembelajaran Fisika (INPAFI), Vol. 8, No. 1, Hal 57-64.

Sujarwanto, E. 2019. Pemahaman Konsep dan Kemampuan Penyelesaian Masalah dalam Pembelajaran Fisika. DIFFRACTION, Vol. 1, No. 1. 
Supiandi, M.I., \& Julung, H. 2016. Pengaruh Model Problem Based Learning (PBL) Terhadap Kemampuan Memecahkan Masalah dan Hasil Belajar Kognitif Siswa Biologi SMA. Jurnal Pendidikan Sains, Vol. 4 No. 2, Hal 60-64.

Togatorop, K.H., \& Sinuraya, J. 2019. Efek Model Problem Based Learning (PBL) Terhadap Peningkatan Kemampuan Pemecahan Masalah Siswa. Jurnal Ikatan Alumni Fisika Universitas Negeri Medan, Vol. 5, No. 4.

Trianto, (2009), Mendesain Model Pembelajaran Inovatif-Progresif. Jakarta: Kencana.

Turnip, B.M., \& Maidita, N. 2015. Pengaruh Model Problem Based Learning Menggunakan Video Pembelajaran Terhadap Hasil Belajar Siswa Pada Materi Pokok Suhu dan Kalor Kelas X SM II SMA N 1 Selesai T.P. 2014/2015. Jurnal Ikatan Alumni Fisika Universitas Negeri Medan, Vol. 1, No. 1.

Valdez, J., \& Bungihan, M. (2019). Problembased learning approach enhances the problem solving skills in chemistry of high school students. Journal of Technology and Science Education, Vol. 9, No. 3, Hal. 282-294. https://doi.org/10.3926/jotse.631.

Wulandari, Eni dkk. 2012. Penerpan Model PBL (Problem Based Learning) pada Pembelajaran IPA Siswa Kelas V SD. Jurnal: FKIP-Universitas Sebelas Maret.

Yuan, H., dkk. 2008. Promoting Critical Thinking Skills Through Problem-Based Learning. Journal of social Science and Humanities. Vol. 2, No. 2.

Yuberti, Latifah, S., Anugrah, A., Saregar, A., Misbah, \& Jermsittiparsert, K. (2019). Approaching problem-solving skills of momentum and impulse phenomena using context and problem-based learning. European Journal of Educational Research, Vol 8, No. 4, Hal 1217-1227.

Zed, Mestika 2003. Metode Penelitian Kepustakaan. Jakarta: Yayasan Obor Indonesia.

Zunanda, M., \& Sinulingga, K. 2015. Pengaruh Model Pembelajaran Berbasis Masalah Dan Kemampuan Berpikir Kritis Terhadap Keterampilan Pemecahan Masalah Fisika Siswa Smk. Jurnal Pendidikan Fisika, Vol 4, No.1. 